\title{
西山記念会館における村野藤吾の設計過程に関する研究 RESEARCH ON THE DESIGN PROCESS OF TOHGO MURANO IN NISHIYAMA MEMORIAL HALL
}

\author{
角田暁治*，福原和 則**，竹内次男*** \\ Akira KAKUDA, Kazunori FUKUHARA and Tsuguo TAKEUCHI
}

\begin{abstract}
Tohgo Murano is one of the most important architects in modernization of Japan. Nishiyama Memorial Hall is his masterpiece by the expression with a free architectural style in the later years of him. The characteristic of his works is the expression that a free curve was used for. The beginning is seen in this work.. In addition, it has clear construction consisting of three cores and Vierendeel truss. Murano produced oil clay models and examined the design of this architecture continuously. By analysis of his architectural drawings, this research checks his design process along a progress chart, and clarifies that actual situation. It is a part of research which clarifies his design intension by verifying design process of Murano.
\end{abstract}

Keywords : Tohgo Murano,Design process, drawing collection, Nishiyama Memorial Hall 村野藤吾，設計過程，図面資料，西山記念会館

1.はじめに

村野藤吾（1891·1984）は、日本の近代を代表する建築家の一 人である。村野は機能や構造が理念的に意匠に反映されること に合理を求为る近代建築全盛期に、ヒューマニズムを理念とし た独自の作風を形成したが、村野の建築史上の位置付汁は未だ に定かではない。村野は中世の工匠のようにものづくりに打ち 込み、その設計図面㻌中過程に過ぎないとされてきた。しか し、その具体的な設計過程を記した記録はなく詳細は不明であ る。本論は初期検討案から竣工間際にいたるまで、村野、森建 築事務所において作成、㭘討された様々な設計図面を分析し、 彼の設計過程から設計方法や作品の特質を明らかにしようとす る研究の一部である。前稿「日本生命日比谷ビルにお汁る村野 藤吾の設計過程に関する研究」注1)は、村野の戦後の代表作の 一つである日本生命日比谷ビルに関する事実を明らかにしたも のであるが、村野の設計過程における特徵を客観的に分析する ために、同様の調査を重㸚ることが課題であった。

本研究は、西山記念会館を研究対象として、前稿と同じ方法 で設計過程を分析するものである。

資料となる村野、森建筑事務所の設計図面は、現在、京都工芸 繊維大学美術工芸資料館に寄託され、同館において設計図面の 整理、研究が行われている。その総数は55,560 枚（2007 年 6 月 16 日現在）である注2\}。収蔵品として登録される設計図面には、 AN.OOOO-OO (AN.はアーカイブNNo.の略) の形式で 1 枚ご
とに番号が付され、名称、シートナンバー、縮尺、サイン、紙 質、筆記用具、製作日時、寸法が記録され、京都工芸繊維大学美 術工芸資料館の年報に順次記載されている。

村野、森建築事務所において保管された設計図面には、途中の 案がしばしば含まれる。設計図面は、竣工時に担当者の判断で 保管された。それらの図面は、竣工後に村野が、「あの図面を 出してくれ給え」と所員に求めた時に困らないようにとの判断 基準で選択されたものであり、それらは村野、森建築事務所の ノウハウの蓄積そのものであった注3)。

\section{2. 分析の方法}

京都工芸瀻維大学が所藏する西山記念会館の設計図面は 440 点である注4)。建筑、構造、設備の各図面、一般図から詳細図、 原寸図まで幅広い種類の図面が含まれる。また、貴重な初期の 検討図や険討スケッチが含まれ、設計段階における検討過程が 記録されている注 5)。

その設計図面を分類して以下の項目を明らかにする。(1)建設 工程と設計図面制作日時 (2)検討案の変遷 (3)着工時図面と䇋 工時図面の比較である。特に(2)についてはダイアグラムを作成 して分析を行う。それらの結果と合わせて関倸する書籍等の調 查、関係者に詨するインタビューを実施して、村野藤吾の西山 記念会館における設計過程からその設計の特質を明らかにする。

Assoc. Prof., Graduate School of Science and Technology, Kyoto Institute of Technology, M. Eng.

Chief Architect, Kajima Design Kansai, Dr. Eng.

Prof., Museum and Archives, Kyoto Institute of Technology, Dr. Eng. 


\section{3、西山記念会館の概要}

西山記念会館（概要を表 1 に示す）は、川崎製鉄の創業者、西 山弥太郎の業績を顕彰するため、川崎製鉄の発祥の地である神 戸本社および葺合工場の隣接地を選んで建設された。建物は一 千人を収容する大ホールを $2 \sim 4$ 階の中心に置き、一階の中央 には、故西山弥太郎社長沛かりの品々を展示する西山記念室、 応接室、談話室、事務所等を配置し、また、5階にはライトコ 一トを中央にして、その周辺に小ホール、クラブ室、娱楽室、 そして地下一階には、中ホール、地下 2 階は機械室と倉庫とな っている。施工は清水建設株式会社が担当した。1976 年 10 月 建築業協会より、優良建築賞（BCS 賞）、1993 年 4 月には神戸 建築百選に選ばれた。

表 1 西山記念会館建築概要

\begin{tabular}{|c|c|}
\hline 所在地 & 神戸市中央区腈浜町 3 T目4番16号 \\
\hline 延床面糟 & $6,349 \mathrm{~m}^{2}$ \\
\hline 構造 & 铁骨コンクリートコアシステム及び鉄骨造 \\
\hline 監数 & 地下2裩、地上5階、塔屋1階 \\
\hline 用途 & 事務所、大ホール(固定718席)、西山記念室、クラブ宔 \\
\hline 外部仕上. & せっ器質タイイルおよび耐侯性銅板 \\
\hline \multirow[t]{9}{*}{ 内部仕上 } & (1階ロビー) \\
\hline & 天井:ラフトン吹付け \\
\hline & 床:ヨ゙ムタイル \\
\hline & (大ホール) \\
\hline & 天井:ラフトン吹付け \\
\hline & 壁:ラフトン欥付汁 床:絊毯敖 \\
\hline & (クラブ室) \\
\hline & 天井:夯ラス絨䑾クロス貼 \\
\hline & 壁:布地又法エースウッド㙋 床:䄉毯敷 \\
\hline 着工 & 1973年(昭和 48年) 9月6日 \\
\hline 竣工 & 1975 年 (昭和 50 年)4月14日 \\
\hline
\end{tabular}

\section{4. 設計過程と設計図面作成月日}

川崎製鉄初代社長、西山弥太郎の偉業を顕彰する数々の記念 事業の一環として、1967年 1 月、西山記念会館の建設が決定さ れた注6〉。1968 年 2 月、第 1 回「西山記念会館建設推進委員会」 が開催され、ホールの基本的な考え方が整理された。1969 年 9 月には第 2 回が開催されるが、その後、景気が後退したため、 一時中断。1973 年 3 月に第 3 回建設推進委員会が開催され、建 家仕様は、ほぼ最終的な姿に収束した。1973年 5 月に第 4 回建 設推進委員会が開催された。この頃、実務担当者による検討、 打合せ会議が頻繁に開催されながら、細部の検討が加えられ、 当初の構想と予算が数回にわたり見直された注7)。

設計者の選定は、文化勲章授章者である丹下健三、村野藤吾 が候補に举がるが、当時の藤本社長の意向で村野藤吾に決定し た。決定時期を示す資料が見当たらないが、設計図面の日付が 確認できる 1972 年 2 月 29 日以前である。

確認申請の日時は 1973 年 2 月 24 日、確認済証は同年 5 月 14 日付で交付された注8)。同年 12 月に第 5 回建設推進委員会が開 催され、各室、設備, 備品が見直された。1974 年 4 月 2 日付で 建築基準法第 12 条第 3 項における一部変更届が提出されている。 同年 9 月 14 日、地鎮祭。工期は䄪 1 年 6 ヶ月であった。工事の 概要を図 1 に示す。建物の底盤全体を基礎とする地下構造、コ
アと呼ばれる $\mathrm{RC}$ 造の階段室に囲まれる立体架構(フィーレン ディール工法) を用いた鉄骨建て方を先行させた工法に特徵が 認められる。翌 1975 年 4 月 14 日に竣工式が行われた。

設計図面作成月日は、図面資料の内容と図面に表記された日 付を調查し、主要なものを時系列に沿って整理したものである。 西山記念会館の初期検討案は、図面日付から表 2 に示すよう

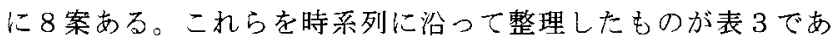
る。図面の日付は1972 年 2 月 29 日が最も古いものであるが、 最初期の検討スケッチは、更にそれ以前に制作されている。実 施案となったA6の日付は 1973 年 10 月 3 日であり、これは着工 直後にあたる。西山記念会館において、一般図による検討は、 着エまでにほぼ完了していたことを示している。表 4 に設計過 程及び設計図面作成月日を示す。

西山記念会館の設計は、A 案、B 案の 2 案の検討から始めら れたことが記録に残されている主9)。A 案は敷地の形状に合わ せた三角形の平面を持ち、刘照的に B 案は北側の外観を最も大 きく見せて東西隅の部分をあけると記してあり、設計図面 $\mathrm{A} 1$ 及 びB1が、その形状から提案された二つの案である。

その 2 案から A1 が選択され、その発展形が A2 である。A3 はA2の青焼図面にスケッチされた検討案。A5-イ、ロはともに A6 の第二原図であり、A5-イが確認申請図、A5-ロが 12 条変更 申請図であると推測できる。A6 は着工直後の日付が入っている ものの、内容㳘成したものと寸分変わらないことから、工事 中の変更点を随時修正したものである。

A4 は正三角形のグリッド図の上に描かれたスケッチである。 実施案へ向けて正三角形の構成が検討され始めた図面群と見ら れる。その平面形状とアプローチ道路形状からA5-イに先立って 作成されたものと考えられる。

鼻先カーブ寸法図（AN.5103-15）、リバテン及び多目的スク リーン部分断面図（AN.5103-17）などの外部詳細図から、B1 階 天井伏図（AN.5103-51）、大ホール壁面展開図（AN.5103-36） などの内部詳細図、1975 年に入り、街灯配置図（AN.5103-47）、 S.T.[構内路平面施工図]（AN.5102-87）などの外構図へと制作 が移行した。

表 2 初期検討案名称

\begin{tabular}{|c|c|c|c|}
\hline 本碖名称 & 図面陪載日時 & A. N No. & 案の位置付け \\
\hline B1 & - & AN5104-24 35他 & 初期提案 B 案 \\
\hline Al & - & AN5104-5̄1 $\sim 59$ & 初期提案 $\mathrm{A}$ 案 \\
\hline A2 & 1972.2 .29 & AN5104-36〜50 & 娭討案 \\
\hline A3 & 1972 & AN5 $103-68 \sim 81$ & スケッキ \\
\hline $\mathrm{A} 4$ & - & AN5 $103-83 \sim 92$ & スケッチ \\
\hline$A \overline{5}-1$ & 1973.2 .24 & AN5 $104-60 \sim 70$ & 確琶申請図 \\
\hline$A \bar{s}-\square$ & 1973.2 .24 & AN5104-02 $\sim 13$ & 12委悡更㖨 \\
\hline A6 & 1973. 10.3 & ANล̄ $102-06 \sim 19$ & 工事用一竣工図 \\
\hline
\end{tabular}

表 3 初期検討案 $の$ 検討過程

\begin{tabular}{|c|c|c|c|c|c|c|c|c|}
\hline 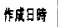 & 不闻 & 1972.229 & 1972 & & 不策 & $\{973.224$ & 不其 & 1973.10 .3 \\
\hline 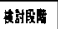 & 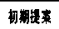 & & & & & 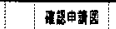 & 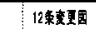 & 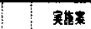 \\
\hline 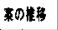 & A1 81 & $\mathrm{~A}_{2}$ & $A_{3}^{3}$ & & A4 & $45-4$ & $45-0$ & $A 6$ \\
\hline
\end{tabular}


表4 建設工程と設計図制作月日

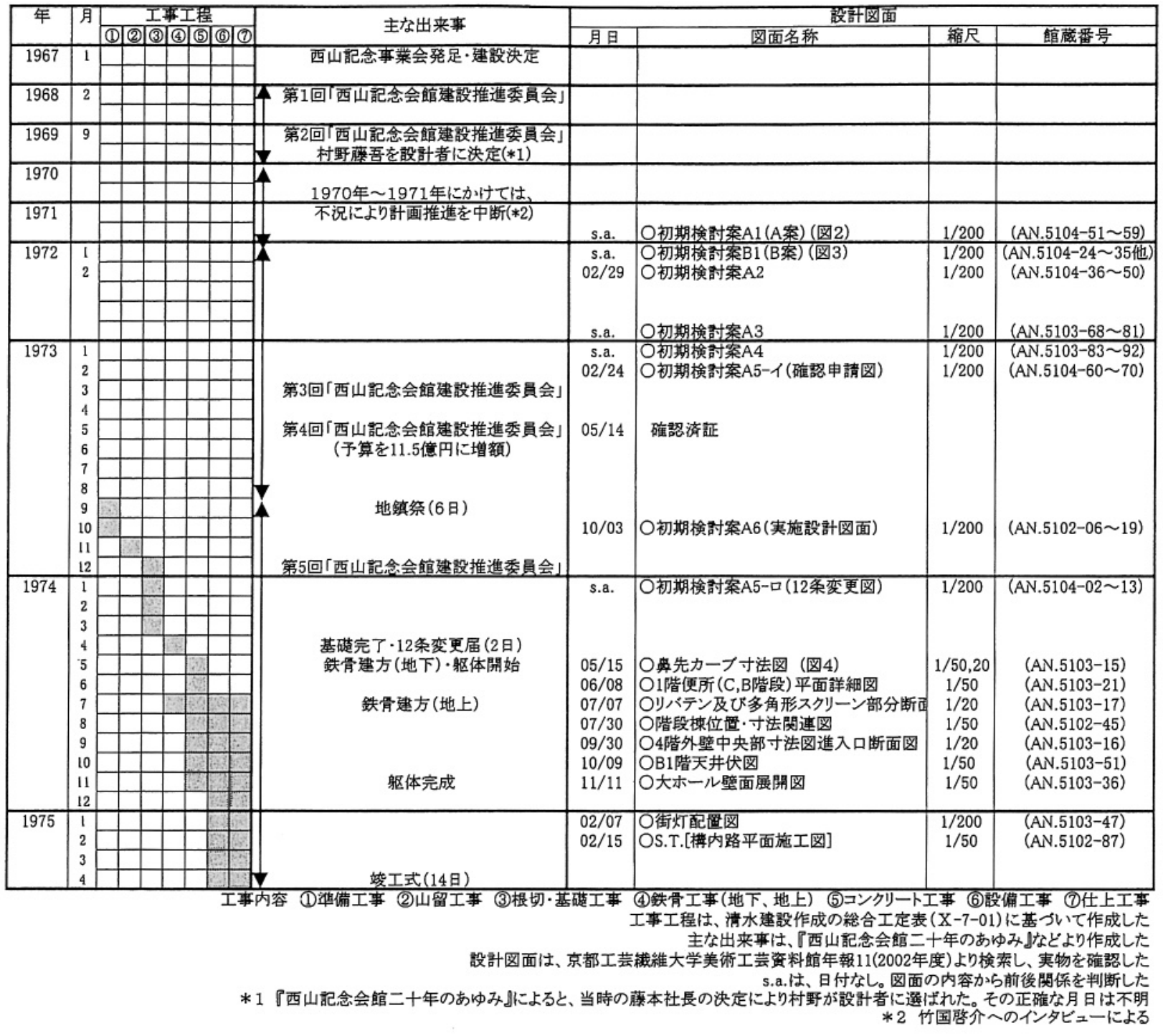

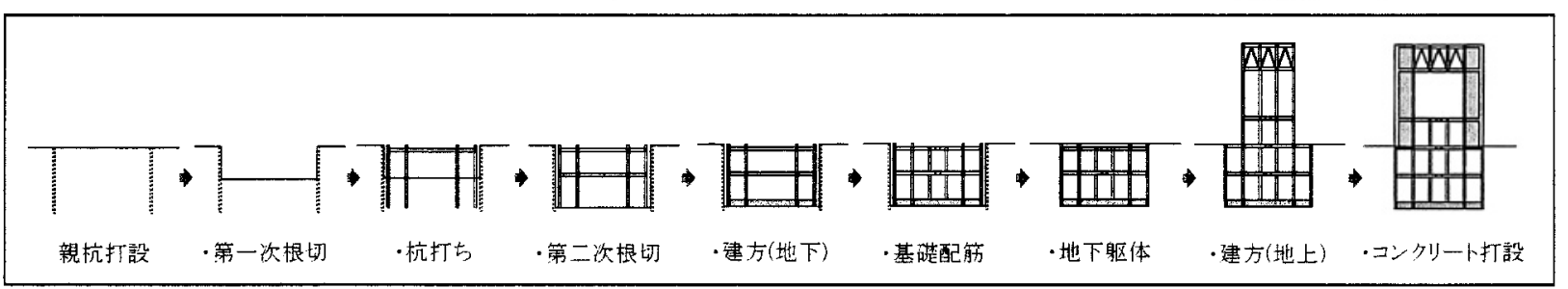

図 1 工事の概要 (手順)

\section{5、模型による検討過程}

村野藤吾は、西山記念会館の設計において模型による検討を 重視した。関係者に対するインタビューおよび文献から明らか になった事実である。

「検郡の初期段階に村野は自ら油粘士による手のひらサイズ の模型を作成した。その検討模型を元に三浦模型の三浦栄次郎 が精度の高い模型を制作。所員であった澤井正宽が石雷で型を 取り、その石高を水平に切断して、平面図を作成した。」注 10$\}$

「事務所の天井に迫る油粘土模型が制作され、村野自身毎日 模型に向かって油粘土まみれになりながら竹べら等で削ったり
盛り付けたりして、納得のいく作業をした。」注(1)

「事務所では、 $1 \mathrm{~m}$ 程度の大きな模型で検討されていた。村野が それをいじって所貣がそれを元に寸法を計って図面化していた。着 工後も模型を用いて外観の検討が行われ、所量が描いた設計図を元 に工事事務所で施工図が作成された。」住 12)

これらの検討過程は、関倸者の記憶が頼りであり、日時の確 定が難しいが、初期検討案 A 4 の 1 階[平面スケッチ]模型用図面 (AN.5103-88) には、「この図面模型用」との表記があり、 その検討段階から、詳細検討のための縮尺 20 分の 1 の模型注 ${ }^{(3)}$ を作成するためのものと仮定できる。 


\section{6. 各険討案における变遷}

\section{6-1 配置計画における変遷}

初期提案 $\mathrm{A} 1 、 \mathrm{~B} 1$ から $\mathrm{A} 2 、 \mathrm{~A} 3$ まで、計画建物はほぼ敷地一杯 の大きさで計画されている。A4 でプランが正三角形になるとと もに敷地内に余白が生じ、 $\mathrm{EV}$ を持つ別棟の非常階段棟と北側 道路からのみ進入できるアプローチ通路が現れる。A4ではアプ ローチ通路を挟んで左右に非常階段棟と本体建物が位置する関 倸にあるが、A5-イでは通路は南北二つの道路をつなぐ形に变更 され、非常階段棟の外側（東側）に配置される。非常階段棟は 本体建物の横に設けられ、そこに立関が設けられる。続く変更 申請図A5-ロでは非常階段棟が再び通路の外側（東側）に変更さ れており、玄関は本体建物東側コアに設汁られる。非常階段棟 は2 階で本体建物とブリッジでつながれ、下部にキャノピーが 設けられる。

\section{6-2 平面構成における変遷}

計画の初期において、村野注「西山会館設計概要」(AN.5103-97) という説明書と共に A， B二つの案を提示している。A案 (A1) は三角形の敷地形状に合わせた案で、三つのコアとそれに支え られたホールという構成を持つもので、B案（B1）は矩形で構 成された案である。「設計概要」では、A案について二ページ を割き、プランの模式図も挿入してその構成や考え方を詳しく 述べているのに対し、B案は一ページに満たない文章のみであ る。また両案とも隣接する川崎製鉄本社ビルとは、形態ではな く色彩により調和させる考えが述心゙られている。

A1 以降の各案において、三つのコアの角度に相違や变更が見 られる。A2をべースとしてその上に描かれたと思和れる A3に おいては、東コアに cooling tower という文字とともに「短かく」 という記入があり、その大きさを縮小する補助線が描かれてい る。また東コアと南コアの角度を小さくして二つのコアを近付 けるように指示されており注 14)、正三角形を基調としたプラン が検討される（A4）以前に、コアのなす角度を均等化している ことが分かる。A4 で全体プランが正三角形となり、建物中央部 分は円形（低層部）及び六角形（高層部）で検討され始める。 1 階平面図（AN.5103-89）では、コア先端部の平面形状に変化 を出すことが指示されている住15)。コアはA1、A2、A3におい ては側面壁の中央部が膨らんだ凸型の平面形状を持つが、コア 自体の形も、正三角形である A4 を経て、A5-イに掠いては逆に 中央部がへこんだ平面となり、実施案(A6)人引き継がれる。

建物中央部分の大ホールは、二つの初期提案 $\mathrm{A} 1 、 \mathrm{~B} 1$ ともに 扇形で、舞台と客席を分節したプロセニアムを備えた平面形で 提案された。A3では円形に近付き、全体平面が正三角形になる A4 以降は円形となり、舞台と客席が一体となる。ホワイエはA2、 A3 では客席背後に設けられている注 16)が、A4 では無くなり、 A5-イにおいては二つのコアとホール内部をつなぐ前室的な空間 として、独立した形で設计られる。しかしA5-口以降においては、 再び客席背後の円形に沿う形で設けられ、実施案 $\mathrm{A6}$ ではそこに
アルコーブ空間が設置注 17)される。

また西山記念室は、初期提案の Al、B1 では一階の中央に配 置され、A1 では六角形、B1 では正方形をべースとして検討さ れた形状が、A1の発展形であるA2、A3 を経て、A4においては 円形となる。 $\mathrm{A} 1 、 \mathrm{~A} 2 、 \mathrm{~A} 3$ とも上部に吹抜を持ち、周囲に設け られた談話、展示スペースと一体となった空間構成が見られる。 しかし、申請図である A5-イでは面積が縮小され、中央部に設置 されていた談話室の側面に配置され、そのまま害施されている。 また中央部で円形に配置された独立柱は、A5-イでは長方形断面 であるが、A5-口以降は円形断面になり、壁面から分離される。

\section{6-3 断面構成における变遷}

各案に㧍ける主要窒の断面構成を表 6 に、代表的な断面図を 図 7 に示寸。B1,A1,A2においては、1 階と地階においてそれぞ れ外部からのアプローチを確保するために、1 F LをG Lより 半階分上げ、北側道路から $1.6 \mathrm{~m}$ の高さを階段で上がってエント ランスに至る注 18) 。しかし、A3において1階レベルを北側道路 レベルに近付ける指示が見られ、A4においてェントランスは北 側前面道路と同一レベルに設定される。

大ホール舞台の設置階は、 5 階 $(\mathrm{A} 1) \rightarrow 4$ 階(A2、A3) $\rightarrow 2$ 階(A4 以降)という変遷を辿り、小ホールは 4 階 $(\mathrm{A} 1) \rightarrow 3$ 階（A2、 A3） $\rightarrow 4$ 階（A5-イ、口） $\rightarrow 5$ 階（A6）上変化している。A1、 A2、A3では、大ホールが最上階で小ホールがその直下階となる が、A4、A5-イ、A5-口、A6 ではその位置関倸が逆となる注 19)。 また大ホールは、A1にはプロセニアムが設けられるが注201、そ の後 A3、A4 で存在が曖昧上なり、A5-イに㧍いて廃止される。 またその形状が屋上部分に突出してくる形がA2に見られるが、 A3 以降には見られない。また初期提案 A，B案とも2 階バルコ ニ一席は無く、一層の客席が階段状に上がっていく断面構成を とっている。A2において2 階バルコニー席が設けられるが、A5イにおいて廃止され、そのまま実現されている。天井の形状は、 A1、B1 から A5-イまで、舞台から客席奥人と上昇する曲面注21) であるが、A5-ロでは舞台上部と客席外周部に反射板状の曲面が 見られるのみで、中央部分住正三角形グリッドで架けられた上 階床の梁（図 5) を現した平天井（図 6 ）となる泩22）。株主棇 会に対応するための昇降式舞台の導入は A5-口以降に見られる。

中ホールは初期検討案 $\mathrm{B} 1$ のみ 3 階にあり、それ以外の案では 地下 1 階に配置されている。A1、A2、A3 では南側道路からの アプローチが検討されているが、A5-イでサービス動線のみとな り、A5-ロ以降はそれも無くなる。

西山記念室は初期提案 $\mathrm{A} 1 、 \mathrm{~B} 1$ から実施案 $\mathrm{A} 6$ に至るまで 1 階 に配置された。A1 では 3 層、B1、A2、A3 では 2 層の吹抜が設 けられていたが、A4 以降は吹技が無くなり寒施に至る。

駐車場は、計画当初より隣接する川崎製鉄本社を利用する予 定であったが、A4においては地下 1 階に駐車場を検討したス久 ッチ（AN.5103-92）が認められる。 


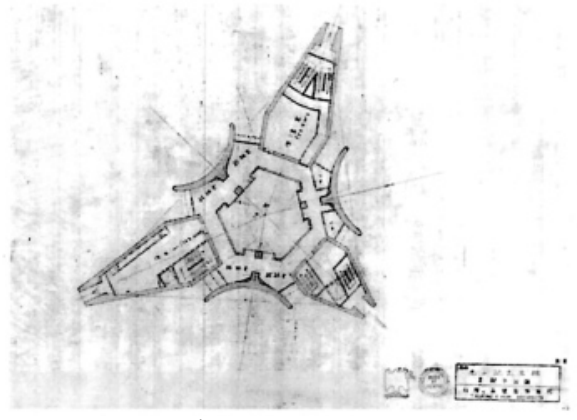

图 2 [A1案]2階平面図 (AN. 5104-52)

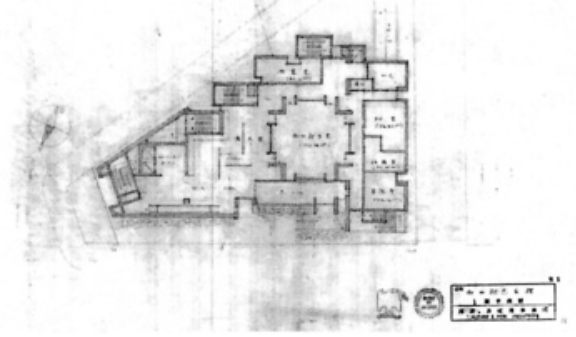

図 3 [B1案]1階平面図 (AN. 5104-25)

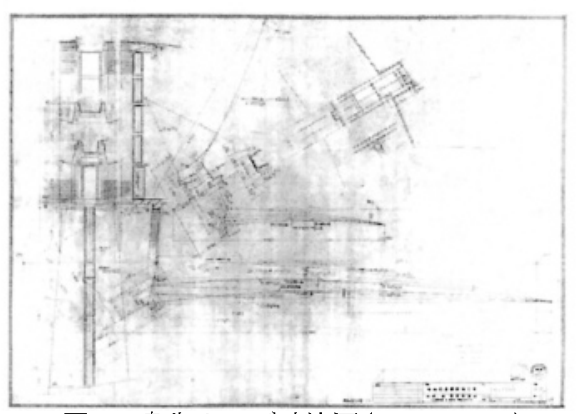

図 4 鼻先カーブ寸法図 (AN. 5103-15)

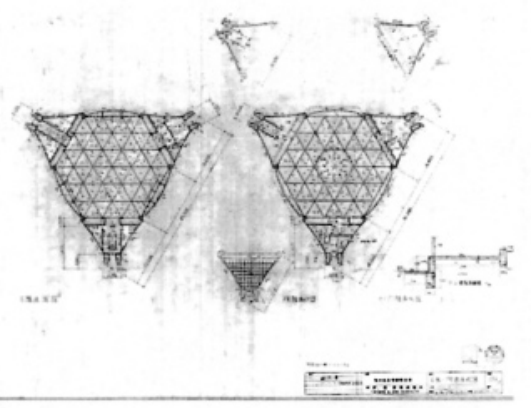

図 5 4階 $\sim P R P$ 階床伏図 $(X-07-05)$

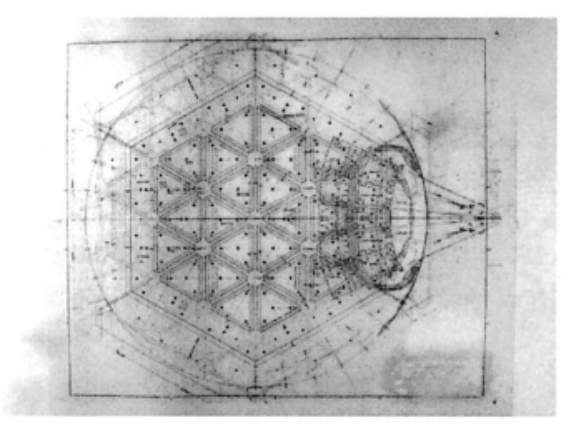

図6 3 階（大ホール)天井伏図 (AN. 5103-41)
表 5 初期検討案のダイアグラム

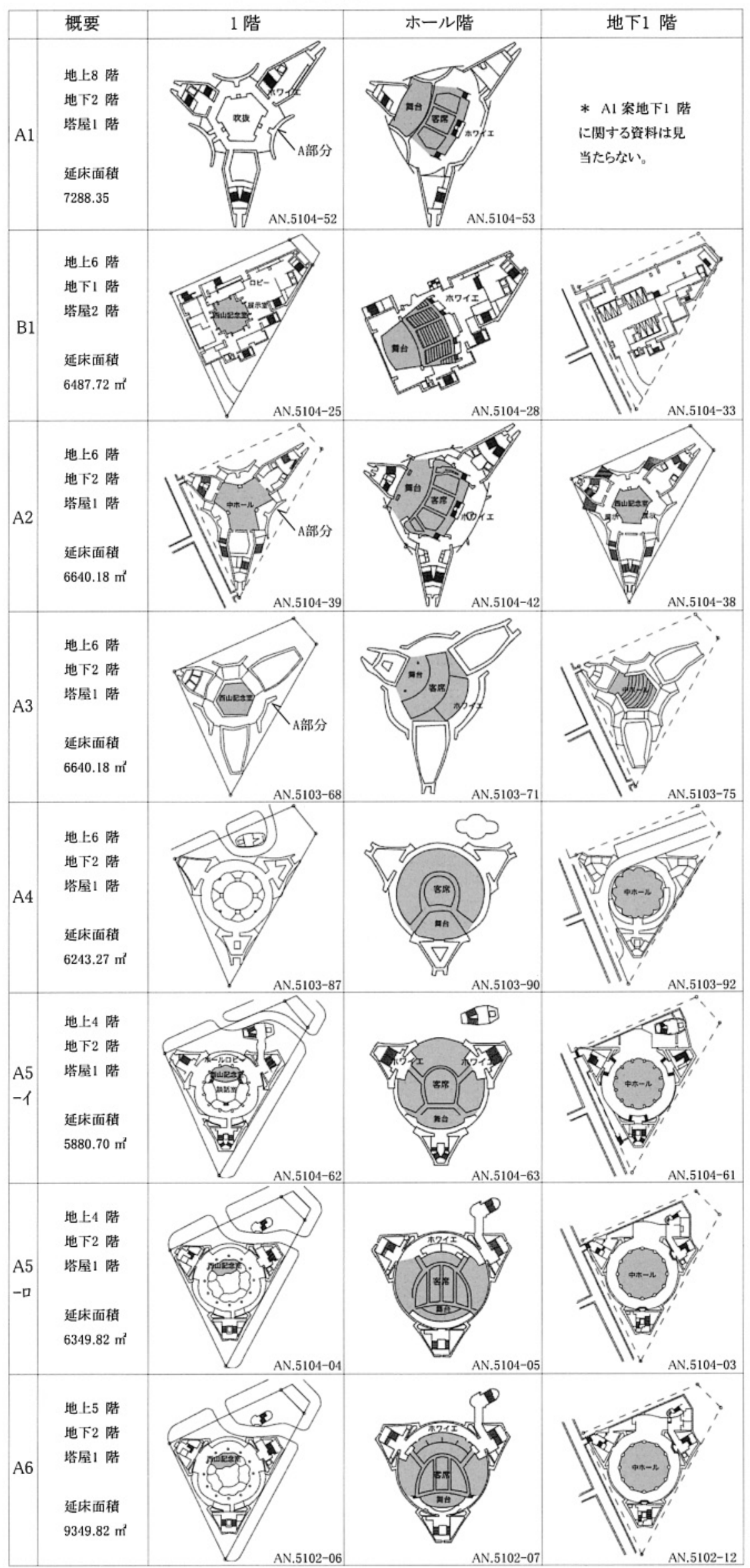




\begin{tabular}{|c|c|c|c|c|c|c|}
\hline \multirow{3}{*}{ 系 } & & & & & & \\
\hline & 诺数 & 西山艳念榇 & 大六一n & 中六-A & 小柰二小 & 1 跮㑛高 $(\mathbf{m})$ \\
\hline & 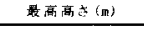 & 吹枝 & & & & \\
\hline \multirow[t]{2}{*}{ B1 } & $\mathrm{B} 1 \cdot \mathrm{F} 6 \cdot \mathrm{P2}$ & 1 䧊 & $4 \sim 5$ 特 & 3 浩 & 2 籍 & $\mathrm{G} \mathbf{L}+0.6$ \\
\hline & $6 \mathrm{GL}+43.00$ & 2 酯 & & & & \\
\hline \multirow[t]{2}{*}{$\mathrm{Al}_{1}$} & $\mathrm{~B} 2 \cdot \mathrm{F} 8 \cdot \mathrm{P}$ & 1 腃 & $5 \sim 8{ }^{2}$ & B1 1 踖 & 小陵 & $G L+1.5$ \\
\hline & $6 \mathrm{~L}-43.013$ & 3署 & & & & \\
\hline \multirow[t]{2}{*}{$A 2$} & $B 3 \cdot F 6 \cdot P 1$ & 4 階 & 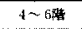 & B I P陵 & 3 幚 & $G L+1.6$ \\
\hline & $6 L-36.75$ & 2 & & & & \\
\hline \multirow[t]{2}{*}{$A^{3}$} & $\mathrm{~B} 2 \cdot \mathrm{F} 6 \cdot \mathrm{P} 1$ & 4 陵 & 4 的㳻 & BI㳻 & 3 & $G \mathbf{G} \pm 0$ \\
\hline & $6 \mathrm{~L}+36.75$ & 2 廉 & & & & \\
\hline \multirow[t]{2}{*}{$\overline{A 4}$} & $B 3 \cdot F \cdot 1 \cdot P_{1}$ & 1 䅂 & $2 \sim 3$ 粯 & B1 & 4 㮆 & $G \mathbf{L} \pm 0$ \\
\hline & $6 \mathrm{~L}+43.00$ & EL & & & & \\
\hline \multirow[t]{2}{*}{$45-1$} & $\mathrm{~B}_{2} \cdot \mathrm{F} 4 \cdot \mathrm{P}_{1}$ & 1 腃 & $2 \sim 3$ 漬 & B士陵 & 4 䑏 & $G L \pm 0$ \\
\hline & $6 \mathrm{GL}+42.30$ & 無 L & & & & \\
\hline \multirow[t]{2}{*}{$A 5-\square$} & В $2, F 4, P 1$ & 1 䧄 & $2 \sim 3$ 封 & 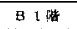 & 4 & $G L \pm 0$ \\
\hline & $G L+24.70$ & 無L & & & & \\
\hline \multirow[t]{2}{*}{$A 6$} & $B 2 \cdot F 5 \cdot P 1$ & 1 略 & 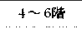 & B 1 陼 & 5 䧄 & $G L \pm 0$ \\
\hline & $G L+24.70$ & 重L & & & & \\
\hline
\end{tabular}

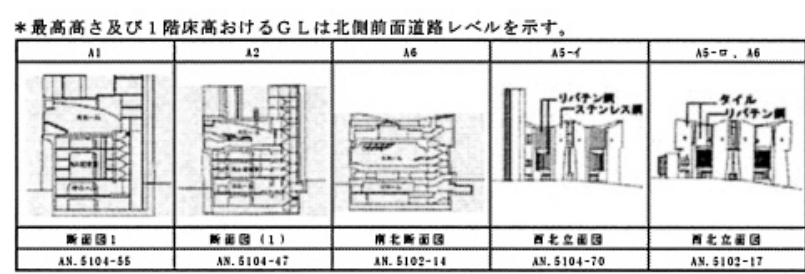

图 7 断面図・立面図

\section{6-4 立面・外観における変遷}

外観に関して、立面図（図 7 ）やスケッチ（図 8）を基に分 析する。これらのスケッチは、その形状から初期提案 A1，B1 の提案以前に描かれたものであることが分かる。

aは、実施案とは異なる形をした最初期の検討案である注23)。 b、cのスケッチには三つのコアが認められる。bは、中央部 に天井の高いピロティ空間が見られるA1以前に検討された初期 の案である往 24)。c は、コアに支えられた中央部が円形に近い プロポーションで描かれている。また $\mathrm{d} 、 \mathrm{e}$ は、直交座標を基 淮に構成され、B1 との類似性が認められる。dでは外壁の凹凸 により、小さなタワーの集合体のような外観が検討されている。 eでは、dと同様の立面スケッチの他に、上部に横長の大きな ヴォリニームを持ち上げた外観が描かれている。スケッチcは A案、スケッチd, e は B 案との類似性が認められ、共通して コア端部形状が検討されている注25)。

断面図（図 7）上り、A1、A2 では三つのコアが中央部分より 高くなっているが、A6では中央部分と三つのコアの高さが近く なり、スカイラインが連続したことが分かる。また立面図を見 ると、確認申請図（A5-イ）ではスカイライン注26) は三方のコア 端部に向けて反り上がる形であるが、A5-口、A6 では、コア上 部のパラペット形状恃曲率を反転させてむくらせた形状となる。 コア部分外装はA5-イではステンレススチール貼であるが、A5ロ、A6では、タイル貼に変更される（図７）。また中央部分に おいては、A1 から A3 までは凹型壁面（A部分：表 5 参照）が 凸型壁面を持つ最上階の大ホールを支えた形であるが、A5-イ以 降は大ホールが 2 階に配置されたことで凹型壁面消消え、中央 部は円形に統一される。

大ホールの上部階は、外壁面形状が A5-イでは直線で構成され るが、A5-ロで曲面となる（図 9)。外装は、A5-イでは大ホー
ル外壁面と同じリバテン鋼注 27) で計画され、中央部分で上下の 一体感が認められる（AN.5104-70）。しかし A5-口(AN.5102 17)では、大ホールの上部階はコアと同じタイルで覆われる往 28) 形態及び外装材において、中央上層部之両端コアは、曲面や夕 イルという共通要素により一体感が生じている。

タイルの貼り方においても村野は極力目地を目立たせずに仕 上げること主29)や、面の折れ線が出ないように曲面を施工する こと注 30) を指示していたことから、表面を覆う仕上材がヴオリ ュームの見え方に及ぼす影響に留意していたことが分かる。

非常階段棟の高さは、A5-イから A5-口に至る過程で川崎製鉄 からの要望により低くなり、内部のEVも無くなっている注31)。

\begin{tabular}{|c|c|c|c|c|c|}
\hline & \multicolumn{2}{|r|}{ 表 7} & \multicolumn{3}{|l|}{ スケッチ分類 } \\
\hline & 表現㘣 & 面種別 & 国の特㳊 & 該当する策 & 由费 AN. No \\
\hline $\mathrm{a}$ & スケッチ/平面 & 外親 & 正方形平面 ビラミット & $\overline{\text { mL }}$ & $1-019-c-04$ \\
\hline b & スケッチ/平面 & 立面 & T字型平面 ピ口ティ & 初期 A 案 & $* 1$ \\
\hline $\mathrm{c}$ & スタッキ/伻面 & 立面・ & 厂字㤠・王焦形平面 & 初期 $\mathrm{A}$ 案 & $* 2$ \\
\hline$d$ & スケッチノ平目 & 咅面 $\cdot \Rightarrow-+-$ - 部 & タロー集棈型 & 机期 B案 & $* 3$ \\
\hline $\mathrm{e}$ & スケッチ/平面。 & 外数 & 多口-乘乘型 & 轵期B案 & $* 4$ \\
\hline
\end{tabular}

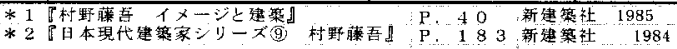

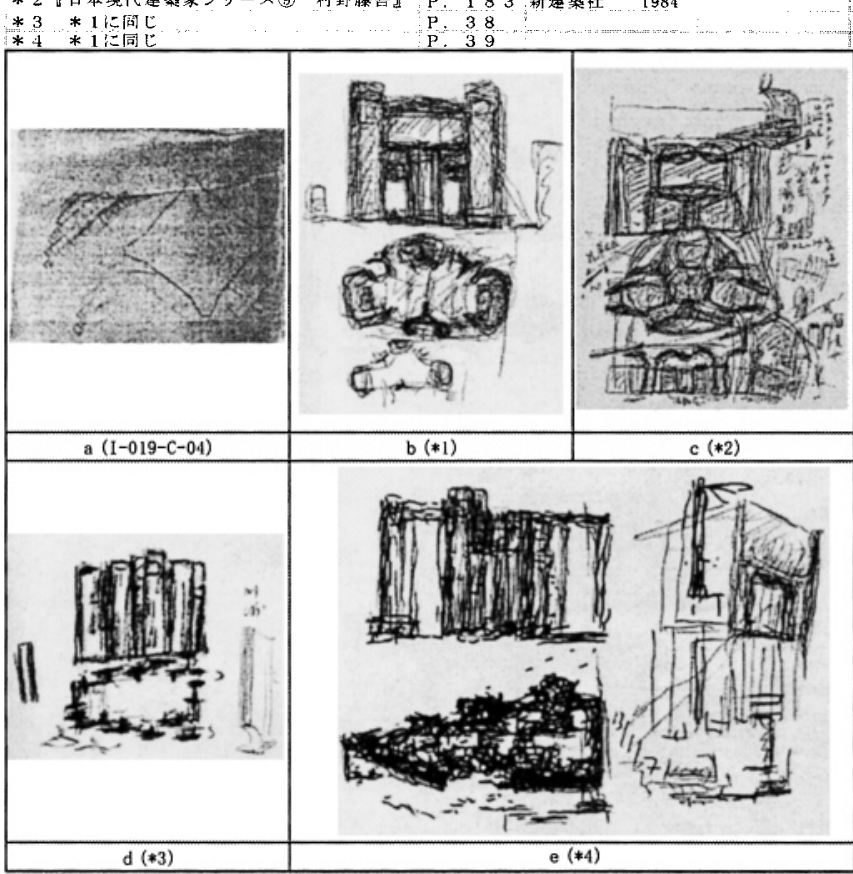

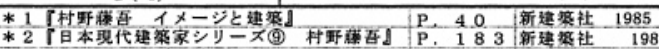

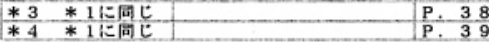

図 8 スケッチ

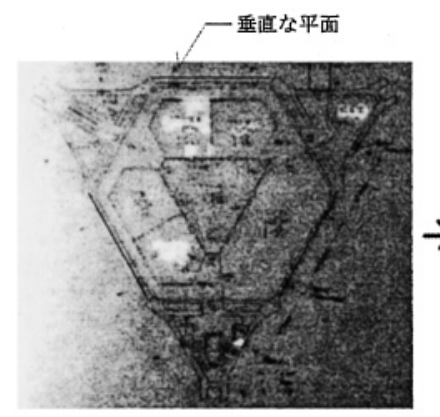

A5-イ 4 階平面因

(AN.5104-65)

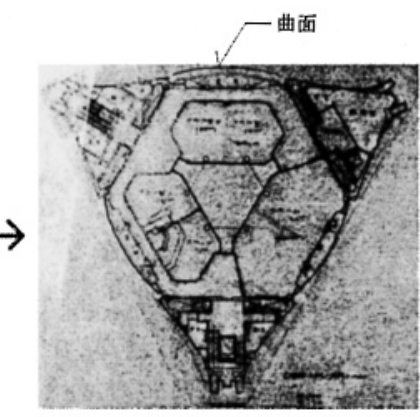

(AN.5102-10)
A5-口 5 階平面図

図 9 中央部分外壁形状の変遷 


\section{7. 工事中の変更事項}

A6 より、着工後の変更内容として、表 $8 、 9$ に示す項目が見 られる。工事の進行と共に、曲面壁の寸法等を模型から採寸し て設計図が起こされ、それを基に施工図が作成された注 32)。変 更履歷にある断面図の<4 階外壁カーブ> (1974.5.15) は中央上 部タイル貼り部分の下端の曲面を指しており、着工後も詳細な 寸法の検討が続けられていたことが分かる。それらは二十分の 一の大きな模型や現場でのモックアップを用いて行われ、場合 によっては施工されたものを見て修正が指示された注33)。

表 8 平面図に打ける変更復歴

\begin{tabular}{|c|c|c|c|}
\hline \multicolumn{4}{|c|}{ 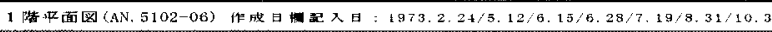 } \\
\hline \multirow{2}{*}{$\begin{array}{c}1973 \\
1973 \\
\end{array}$} & \multirow{2}{*}{$\begin{array}{l}10 \\
11 \\
\end{array}$} & \multirow{2}{*}{$\begin{array}{r}12 \\
1 \\
\end{array}$} & クロークカウンターホール入り口 $\mathrm{S} H$ H新配 \\
\hline & & & 柱型 \\
\hline 1974 & 5 & 14 & $w \subset$ 先密形执 \\
\hline 1974 & 12 & 10 & 欺話至出入口 \\
\hline \multicolumn{4}{|c|}{ 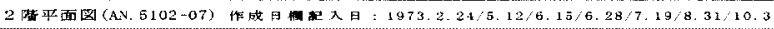 } \\
\hline 1973 & 11 & 1 & 柱型 \\
\hline 1974 & 8 & $\circ$ & (空樗) \\
\hline \multicolumn{4}{|c|}{ 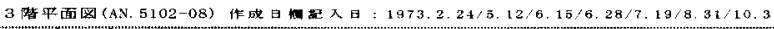 } \\
\hline 1973 & 11 & 1 & 柱整 \\
\hline \multicolumn{4}{|c|}{ 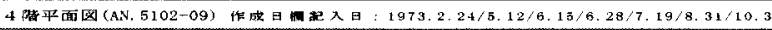 } \\
\hline 1973 & 11 & 1 & 柱型 \\
\hline \multicolumn{4}{|c|}{ 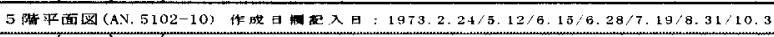 } \\
\hline 1973 & 11 & 1 & 柱型 \\
\hline \multicolumn{4}{|c|}{ 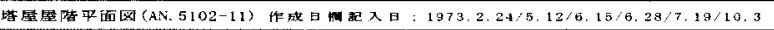 } \\
\hline 1973 & 10 & 16 & 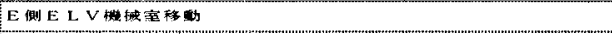 \\
\hline 1973 & 11 & 1 & 柱型 \\
\hline \multicolumn{4}{|c|}{ 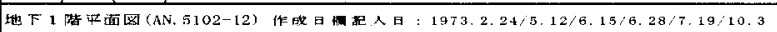 } \\
\hline 1973 & 10 & 5 & 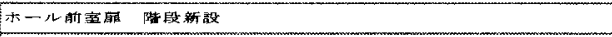 \\
\hline 1973 & 11 & 1 & 枉型 \\
\hline 1974 & 5 & 14 & 离侧便所 \\
\hline \multicolumn{4}{|c|}{ 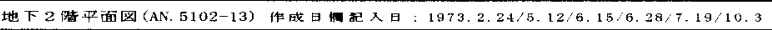 } \\
\hline 1973 & 11 & 1 & 柱型 \\
\hline 1973 & 12 & 24 & 12 本䄇，九保 \\
\hline 1974 & 2 & 21 & Рテーリンク C僣段林レで \\
\hline 1974 & 5 & 14 & 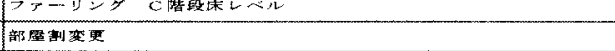 \\
\hline
\end{tabular}

表 9 断面・立面図にお忖る変更履歷

\begin{tabular}{|c|c|c|c|}
\hline \multicolumn{4}{|c|}{ 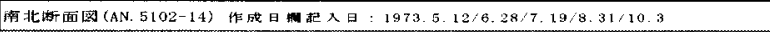 } \\
\hline 1974 & 2 & 18 & $B 2 F>P-y=7$ etc. \\
\hline 1974 & 5 & 15 & 大ホール天井 $4 \mathrm{~F}$ 外暨カーフ \\
\hline \multicolumn{4}{|c|}{ 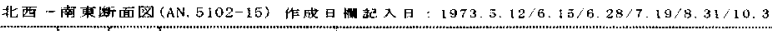 } \\
\hline 1974 & 2 & 18 & : \\
\hline 1974 & 5 & 15 & 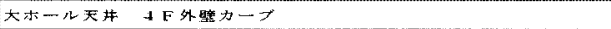 \\
\hline \multicolumn{4}{|c|}{ 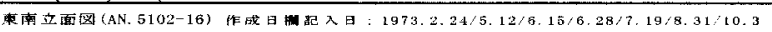 } \\
\hline 1973 & 5 & 11 & \\
\hline 1974 & 2 & 22 & 先りバンンータイル \\
\hline 1974 & 5 & 14 & 通入口形状 \\
\hline \multicolumn{4}{|c|}{ 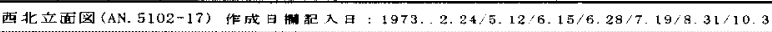 } \\
\hline 1973 & 5 & 11 & \\
\hline 1974 & 2 & 22 & 先リバテンータイル \\
\hline 1974 & 5 & 14 & 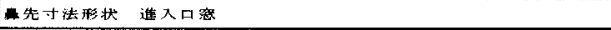 \\
\hline \multicolumn{4}{|c|}{ 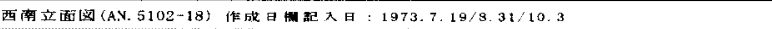 } \\
\hline 1974 & 2 & 22 & 先リバフンンータイル \\
\hline \multicolumn{4}{|c|}{ 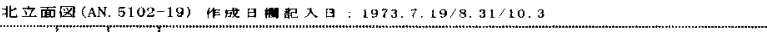 } \\
\hline 1974 & 2 & 22 & 先リベテンータイル \\
\hline
\end{tabular}

\section{8. まとめ：西山記念会館の設計過程}

本稿の検証によって、以下の内容が明らかになった。

1) 初期の提案としてパースやスケッチによる検討を経て、三 角形平面を持つ $\mathrm{A} 1$ 及び矩形平面の $\mathrm{B} 1$ の二案が提案され、 $\mathrm{A} 1$ 案を基に設計が進められたことを設計図面から確認した。

2) 平面構成では Al、B1の双方において「西山記念室」が平 面の中央に配置された。A2、A3、A4においても同様であった が、A5-イではその面積が縮小されるとともに、中央に「談話空」
が配置される。西山記念室が中央に配置された記念性を重視し た構成から、談話・交流機能を重視した構成へと変化した。

3）大ホールは当初、舞台と客席を明確に分節したプロセニア ムを備えた形式で計画が始められたが、設計の進行とともに講 演会を主目的と寸る、舞台と客席が一体となった平面形に変化 した。断面においては曲面天井から、構造体を意匠的に現した 平天井へと変化した。

4) 外観においては、A1、A2 では三つのコアが中央部分より 高かったが、A5-イでは近い高さとなりスカイラインが連続した。 A5-ロでは中央部の上層部分と三つのコアが連続した曲面形状と なり、同一タイルが貼られた。一方、大ホールの外壁部分のみ リバテン鋼板貼の仕上げとなり、その他の曲面部分とは異なる 直線を基調とした立面形状となった。

5）平面形状においては、初期提案 A1、A2、A3 では、凸型平 面のコアと凹型平面の中央部分で平面が構成されていたが、 $\mathrm{A} 4$ 以降の案においては、コアが凹型、中央部分が凸形（円形）と なった。組合せは異なるものの、コアと中央部分の平面形を凹 凸をもつ壁面で構成するアイデアは共通している。

6)設計図面の変更履歴から、着工後の大きな変更点は確認でき ない。確認申請提出後、工事着工までの間に 12 条変更申請が提 出され、ほぼその形で竣エしている。そのことから一般図にお いては、着工時に最終形に近い案になっていたことが明らかに なった。工事中の変更項目は、曲面の寸法や各部のディテール に限られる。

7) 以上の結果から、西山記念会館における村野藤吾の設計過程 の特徴が明らかになった。複数案の検討により案の方向性を決 めた後、施主要望に基づいて建物規模や機能構成を調整した。 次に外壁面の形状と素材の検討を行い、工事着工後㳉細部の形 状や寸法の決定を行った。建物形状が有機的な形態であるため に、デザインの検討においては模型が重要なツールであった。

西山記念会館は、村野建築の特徵の一つである、手の痕跡を 感じる曲線や曲面を持つ作品である。その設計過程は、建物竣 工に至るまで、自らの求める形や空間を追求し続けるむのであ った。それは、熟練した職人が少なくなり、設計や施工におけ る工業化と合理化が進められる現代にあって、ものづくりに携 わる者にとり示唆に富むものである。その独自性と価值を明ら かにするためにも、引き続き最晚年の作品において同様な検証 を行うことが今後の課題である。

\section{謝辞}

本稿に执いて、資料提供や聞き取りなど、調查にご協力頂いた 西山記念会館、J F E 、清水建設の関係者の皆様、並びに村野、 森建築事務所元所員の皆様に厚く御礼申し上げます。 
注1) 福原和則、竹内次男、船越運由、日本生命日比谷ビルにおいる村野藤吾の設計 過程に简与研究、日本建築学会計画系論文集 615 号、pp. 229 236、2007. 5

注2）京都工芸瀻維大学美術工芸資料舵において、村野藤吾の設言十図面のフォルダを管 理する帳票である総合りスト（Togo Murano Drawing Lis）には、フォルダ毎に枚数

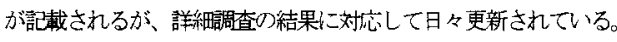

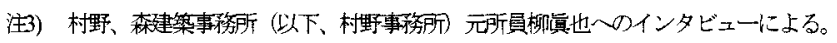
(日時: 2005. 5. 6、關手: 西島一福原和則)

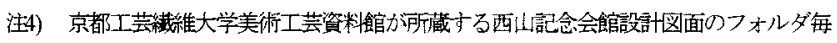
の内訳怯、AN. 510293 枚)、AN. $5103(97$ 枚)、AN. $5104(81$ 枚)、X 07 (29校)、X-36-A (91校)、X-36-B (49 枍)である。

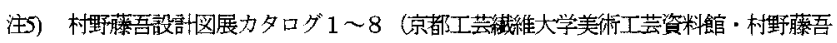
の設計研究会、2000 2007) に詳しい。

注6)浅川秀雄他、「西山記念会館建設の程緯」、『西山記念会館二十年のあゆみ』、 pp.1-3 「二十年のあ虬み、編集委員会、1995. 12

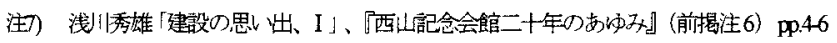

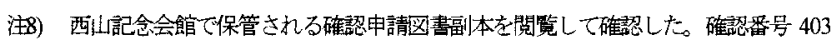
号、確認年月日昭和 48 年 5 月 14 日であり、昭和 49 年 4 月 2 日付の 12 条 3 項に よる一部変更届か礁羿できた。

(前掍注 6

注10）村野事務所元所負澤井正宽へのインタビューによる。（日時：2007. 8. 28、聞手： 福原和則》

注11）小森一憲「建設の思、出、II」、『西山記念会館二十年のあゆみ』（前提注6）

注12）清水建設工事事務所で施工図索担当していた山木戸浄治へのインタビューによる。 (日時 : 2007. 8. 30、聞手 : 角田兟治)

注13）検言比あって、20 分の1の模型を作成したことが、西山記念会館事務長・柿本 泰三、建設当時儿崎製鉄の担当として施工管理に従事した竹国啓介へのインタビ ューによって明らかである。（柿本泰三、日時：2007. 6.28、聞手：角田曉台、

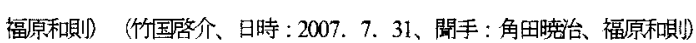

注14)三つのコアの中心線の為す角度は $\mathrm{Al}$ 及じA2 でさ $134^{\circ} 、 113^{\circ} 、 113^{\circ}$ で支るが、 $\mathrm{A} 3$ 以降は $120^{\circ}$ ぶの構成に変更される。

注15）三つのコアそれでれに先端部位置を示方線とともに「上「下」と記入され、上 層階か下下聪階よりオーバーハングする形批示されている。

注16) A3 案4階平面図（AN.5103-71）に扑て、ホワイエの中央に立つ柱にメ印が拊け られている。A3 案では各階平面図に六角形を基準とした柱位置が朱書きされてお り、上り幾何学的な整合性を持つ正三角形の次案A4の萠芽が見られる。

注17）柿本泰三（前揭注 13）によると、株主総会での相談スペースとして設けられたよ うである。着工時のA5-ロではその部分は「電算室」「備室」となっている。

注18）村野は「西侩会節設計概要」において、一一階への出入口は北側にとり、二ヶ所 より特洱階段から昇降して出入りすることは、主階の重要性を意味するような印 象を与えるものと考える。上述心゙その意図に言及している。

注19）A4 案4階平面図（AN5103-86）の中に、邺見されたものの原型となる断面スケッ チか認められる。上層部をフィーレンディールトラスが冊み、地上レバルでは垂 直荷重を支える柱が中央付近に配置された構成は、そのまま奏現されている。

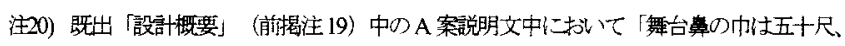
プロセニアムの高さは二十二尺位にとり」との記述がある。

注21) プロセニアム形状の屋上への突出及びホール長手方向の断面形状の在り方におい ては、「米子市公会堂」(1958)のホール断面との類以性が見られる。

注2）山木戸浄治に上る上、楧造体を現した天井のデザインは、鉄骨建方が完了した後、 構造設計者である前/陽一の進言により変更された。（前揭注 12）

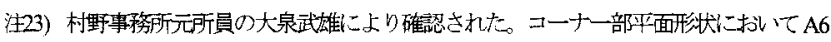
のコア端部形衐上の類以点が見られる。

注24）村野事務所元所員の犬楕一夫によると、初期のスケッチでは「中央のホールを空

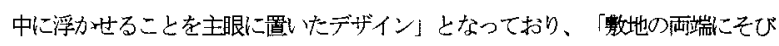
え立つ三つのコアで、ホールなどの各部屋を上の方一持ち上げ、その下块井の 非常に高いピロティとして、広場を設け」る案であったようである。『西山記 念会館二十年のあ神み』（前揭注6） p.24

注25）垂直に伸びるスリット状の端部処理と、それが地上付近において内 側に抉られる形状が検討されているが、西山記念会館が端工寸る前年竣

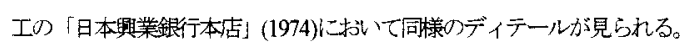

注26）村野はデザインのボイントとして壁などの端部や境界、スカイライン等を「ハシ バシ上呼び、重要視していた「「私は事務所でよく、始まりと終わりに気をつ けろといってい主す。たとえは壁面の一番終わりと空の始まり。それが境界とい

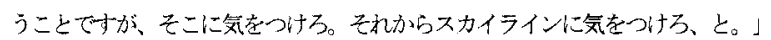

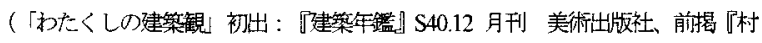
野藤吾著作集 $\mathrm{p} .696$ 所双）等にその意墥を見ることが出来る。

注27）村野事務所元所員澤井正寞によると、リバテン鋼板の採用に当たっては、浪速組 東京支占(1966)0外壁でコルテン鍓を用いた経験を踏まえて、自信を持って採用し たようである。前揭注 10

注28）外壁什上にかいて村野は「場地帯であるから、はじめは黒っぼ、色を考えてい

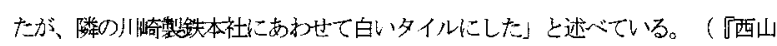
記念会馆二十年のあゆ戏 前提注6 p.24) タイルは污れが付きにくい素材とし て決定されたようであるが、案 A4 の4階平面図(AN5103-86)の董面には「(1)コル テン仮枠、(2)ステンレス黑板、(3)夕イルレンガ風、及びD上(2)にかては「パ 一ス2案の色で書くこと」との書き込みがあり、外装の検言過程が伺える。

注29）竹国啓介へのインタビューによる。前揭注 13

注30）清水建設で施工管理を担当した飯境雅文によると、村野は曲面壁の曲漳が変わる 部分を滑らかに什上げて、線が出ない上うにするこ上を指示している。(インタ ビェ一日時 : 2007.8.24/聞手 : 角田䀘治)

注31）非常谐段徚の高さはA5-イでは42.3mであるが、A5-口では $24.7 \mathrm{~m}$ Łいうように縮

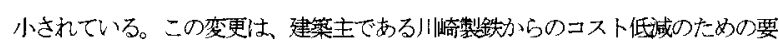
望であった。『西山記念会館二十年のあ奴》（前揭注6） p.8

注32）外壁の曲面部分は模型を計測して図面化された。(山木戸浄治へのインタビューに よる。前揭注 12)

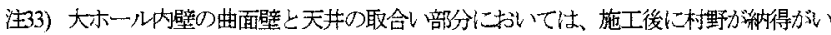
が、゙、寸法を换封して施工のやり直しが行われた。（山木戸浄治へのインタビュ 一による。前掍注 12)

(2007年 9 月 10 日原稿受理, 2008 年 1 月 23 日採用決定) 